\title{
Primary Gallbladder Pleomorphic Sarcoma: A Rare Case
}

\section{Primer Safra Kesesi Pleomorfik Sarkomu: Nadir Bir Olgu}

\section{Olgu Sunumu Case Report}

\author{
Semra Demirli Atıcı ๑, Halit Batuhan Demir ๑, Değercan Yeşilyurt $\odot$, Dudu Solakoğlu ๑ \\ Mehmet Üstün $\odot$, Cengiz Aydın®
}

\begin{abstract}
Primary gallbladder pleomorphic sarcoma is a very rarely seen type of tumor and its prognosis is not well known mainly due to the limited number of cases reported. Here, we present a case with primary gallbladder pleomorphic sarcoma of which diagnosis was based on morphology and immunohistochemistry.

A 70-year-old male presented with three months of abdominal pain in the upper right quadrant and weight loss. The patient reported a past medical history of chronic cholecystitis. Using abdominal magnetic resonance imaging (MRI), the patient was diagnosed with gallbladder cancer. Radical cholecystectomy, with segment $4 b$ and 5 resection of the underlying liver tissue and dissection of the pericholedochal lymph nodes were performed. Patient's postoperative course was unremarkable and he was discharged on the postoperative $5^{\text {th }}$ day. The immunohistochemical analyses supported the diagnosis of primary gallbladder pleomorphic sarcoma. The patient was referred to the department medical oncology for adjuvant chemotherapy

Primary gallbladder pleomorphic sarcoma is a very rare histological type with an unclear pathogenesis. A better understanding of pathogenesis and treatment for this disease, with the larger case series may be better addressed.
\end{abstract}

Keywords: Gallbladder, pleomorphic sarcoma, laparoscopic cholecystectomy

öz

Primer safra kesesi pleomorfik sarkomu çok nadir görülen bir tümör tipidir ve literatürde bildirilen olgu sayısının sınırı olmasından dolayı iyi bilinmemektedir. Bu yazıda postoperatif immünhistokimyasal inceleme ile tanı konulan primer safra kesesi pleomorfik sarkomlu bir olgu sunuldu.

70 yaşında erkek hasta, sağ üst kadranda üç aydır olan karın ağrısı ve kilo kaybı ile başvurdu. Hastanın özgeçmişte kronik kolesistit nedeniyle medikal tedavi öyküsü mevcuttu. Kapsamlı radyolojik görüntüleme ile hastaya safra kesesi kanseri tanısı konuldu. Hastaya radikal kolesistektomi, karaciğer segmen $4 b, 5$ rezeksiyonu ve perikoledokal lenf nodu diseksiyonu uygulandı. Postoperatif dönemi kompllikasyonsuz seyreden hasta postoperatif 5. günde taburcu edildi. Postoperatif immünhistokimyasal incelemeler primer safra kesesi pleomorfik sarkom tanısını destekledi. Hasta adjuvan kemoterapi için tıbbi onkoloji bölümüne yönlendirildi.

Primer safra kesesi pleomorfik sarkomu belirsiz patogenezli çok seyrek görülen bir histolojik tiptir. Daha geniş serili çalışmalarla bu hastalığın patogenez ve tedavisinin daha iyi anlaşılabilir.

Anahtar kelimeler: Safra kesesi, pleomorfik sarkom, laparoskopik kolesistektomi

\section{INTRODUCTION}

Primary sarcoma of the gallbladder (PGBS) is rarely seen malignancy, with only 40 cases reported in the literature ${ }^{(1)}$. Clinically most of the patients present with right upper quadrant pain with or without jaundice, with symptoms of acute and chronic cho- lecystitis, weight loss, pruritis, palpable mass, biochemically elevated alkaline phosphatase or bilirubin ${ }^{(1)}$.

We herein present a 70-year-old male with primary pleomorphic sarcoma which is a rare type of gallbladder cancer. SBU. Tepecik Eğitim ve Araştırma Hastanesi, Patoloji Anabilim Dalı, izmir, Türkiye

(c) Copyright Association of Publication of the T.C. Ministry of Health Izmir Tepecik Education and Research Hospital.

This journal published by Logos Medical Publishing. 


\section{CASE PRESENTATION}

A 70-year-old male presented with three months of abdominal pain in the upper right quadrant and weight loss. The patient reported medical history of chronic cholecystitis. Laboratory analysis revealed hemoglobin of $6 \mathrm{~g} / \mathrm{L}$, and a normal leukocyte count. Tumor markers including serum carcinoembryonic antigen, carbohydrate antigen 19-9 (CA 19-9) and $\alpha$-fetoprotein (AFP) levels, and liver function test results were within normal levels. Abdominal ultrasonography revealed a $3 \mathrm{~cm}$ gallbladder stone and irregular wall thickening of the gallbladder. Abdominal magnetic resonance imaging (MRI) showed irregular wall thickening of the gallbladder, mass lesion size $112 \times 63 \mathrm{~mm}$ completely filling the gallbladder and extending into liver with parenchymal invasion (Figure 1). The preliminary diagnosis was gallbladder cancer. A radical cholecystectomy, with segment $4 \mathrm{~b}$ and 5 resection of the underlying liver tissue and the pericholedochal lymph nodes were performed.

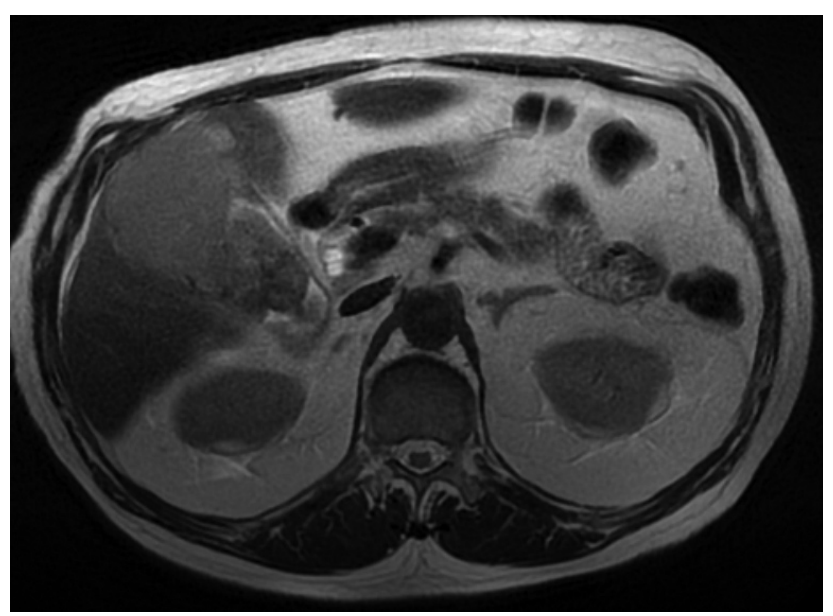

Figure 1. Preoperatively Abdominal magnetic resonance imaging (MRI) shows irregular wall thickening of the gallbladder and mass lesion size $112 \times 63 \mathrm{~mm}$ completely filling the gallbladder and expands the liver.

On postoperative second-day oral intake was begun and abdomen drainage catheter was removed on postoperative third day. Patient's postoperative course was unremarkable and he was discharged on postoperative $5^{\text {th }}$ day.

The histopathological examination revealed a $5 \times 5 \times 4$ $\mathrm{cm}$ tumor, which originated from the fundus of the gallbladder and filled the entire gallbladder lumen and extended into the liver. An immunohistochemical examination demonstrated positive staining for CD68-PGM1, vimentin, S100, actin, smooth muscle actin (SMA), negative for CK18, CD 117 and DOG-1 (Figure 2, Figure 3). Postoperatively adjuvant chemotherapy were recommended. The patient is still being followed up at postoperative fifth month.

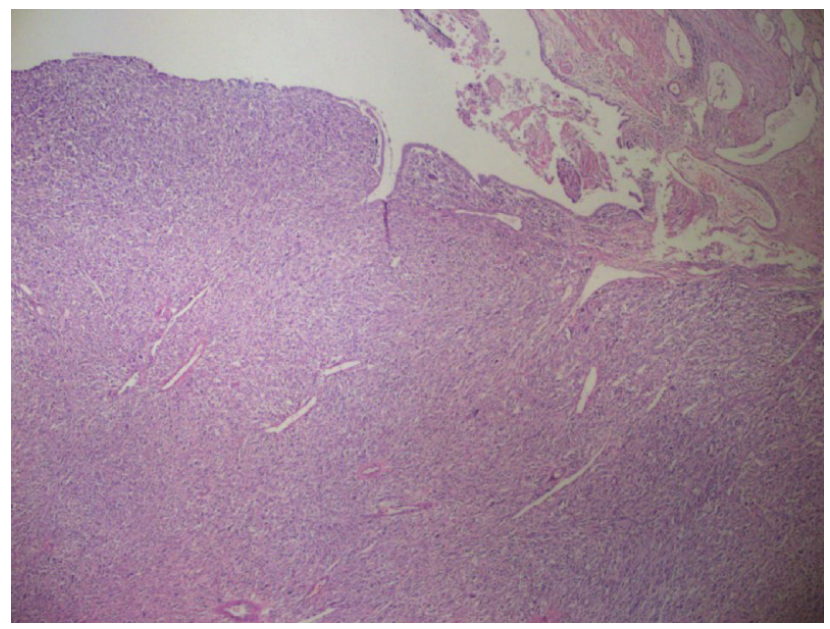

Figure 2. Pleomorphic sarcoma under the gallbladder epithelium, H\&E, $\mathrm{x} 40$.

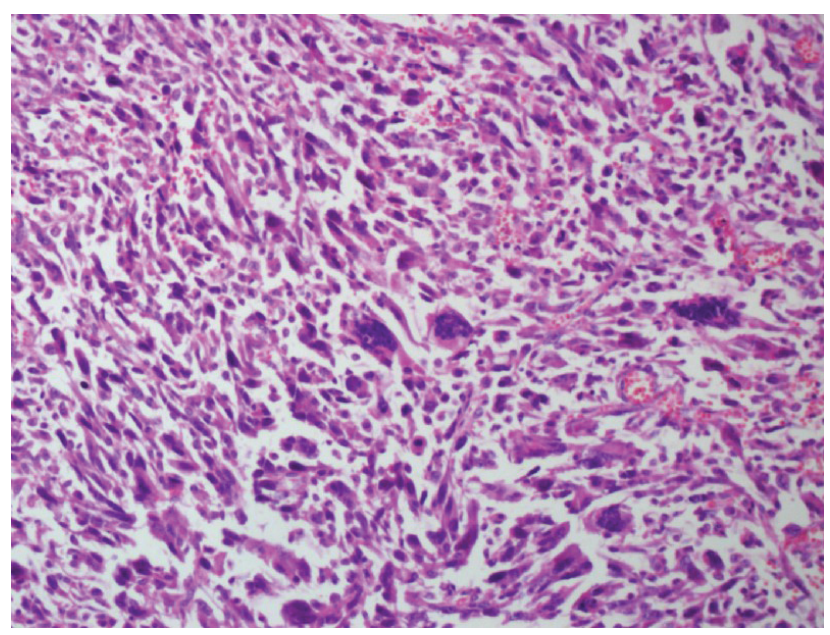

Figure 3. Atypical mesenchymal cells, H\&E, x200.

\section{DISCUSSION}

PGBS is most commonly seen in the seventh decade of life as gallbladder cancer, and its diagnosis is mostly based on postoperative specimen reports 
revealing its immunohistochemical and morphological features. The disease mainly occurs in older female adults two times higher than in men with symptoms of acute cholecystitis, and it has overall poor prognosis ${ }^{(1-3)}$. The symptoms and signs of gallbladder sarcomas are nonspecific. Clinically most of the patients present with right upper quadrant pain with or without jaundice, loss of appetite, palpable mass, hyperbilirubinemia, weight loss, vomiting, pruritis, symptoms of acute and chronic cholecystitis, and elevated alkaline phosphatase levels ${ }^{(1,2)}$.

Risk factors and pathogenesis of PGBS is poorly understood. Mostly abnormal bile composition that causes stones, cholelithiasis with accompanying cholecystitis is blamed Irritation and chronic inflammatory changes have been suggested as promoting factors in the pathogenesis of PGBS ${ }^{(2-4)}$.

In literature most cases reported have gallbladder sarcomas, and the patients were thought clinically to have gallstones ${ }^{(1,2)}$. History of gallstone disease and size of gallstone are known to be associated with gallbladder cancer risk ${ }^{(3-5)}$. Gallstone is the mostly known risk factors for gallbladder sarcomas and gallbladder cancer. Ninety-five percent of patients who are diagnosed with gallbladder cancer have gallbladder stone and also 65 \%of patients who are diagnosed with gallbladder sarcoma have gallbladder stones ${ }^{(1-3)}$. Although polypoid lesions of the gallbladder which are especially $>10 \mathrm{~mm}$ in diameter, gallstones that are larger in size $(>3 \mathrm{~cm})$, calcified "porcelain" gallbladder, infections like Salmonella spp.and Helicobacter pylori can increase the risk of gallbladder cancer, any study in the literature has not demonstrated them as risk factors for gallbladder sarcoma so far ${ }^{(3-5)}$.

Based on literature findings, median tumor size is 4.5 $\mathrm{cm},(2.0-14.0 \mathrm{~cm}$.), and mostly tumors have involved the body or fundus as in our case ${ }^{(1)}$. Preoperatively, the imaging methods and laboratory tests cannot aid in establishment of definitive diagnosis of PGBS.
Generally, as in our case, the patients zhave been operated due to the preoperative suspicion of malignancy. The definitive diagnosis is made with by the postoperative immunohistochemical analyses. Gallbladder sarcoma can be separated from spindle cell carcinoma, melanoma and gastrointestinal stromal tumor (GIST) ${ }^{(1,2)}$. First of all, CK18-negativity rules out the diagnosis of spindle cell adenocarcinoma Then GIST which is characterized by a spindle cell proliferation that is positive for CD117 and DOG-1 could be excluded. As in our presented case, CD117 and DOG-1-negativity ruled out the diagnosis of GIST $(6,7)$.

Generally, biological behavior of PGBS is aggressive, mostly it is seen as a locally advanced disease with a poor prognosis. Most cases of PGBS has been revealed at an advanced stage and showed rapid growth characterized with a large mass. With limited experience of primary pleomorphic sarcoma of gallbladder, its long-term survival rates are not well known. The prognosis of this disease is normally poor ${ }^{(1,2)}$. The common treatment for gallbladder cancer is surgical resection, but there is no consensus about the management, because of limited experience with this disease. PGBS mostly manifests itself as a locally advanced disease because simple cholecystectomy doesn't provides satisfactory cure for tumors confined to the gallbladder wall. For surgical treatment of PGBS, extensive resection and adjuvant chemoradiotherapy has been suggested in the presence of gallbladder carcinoma ${ }^{(2)}$.

In conclusion, primary pleomorphic sarcoma of the gallbladder is a very rare seen histological type with an unclear pathogenesis mainly due to a limited number of cases reported. As in our case, gallstones which are larger than $>3 \mathrm{~cm}$ may carry a risk of pleomorphic sarcoma. But, it will be necessary to accumulate more case reports of this tumor in order to define different risk factors which might be helpful in optimizing the treatment for this specific rare type of tumor. 
Conflict of Interest: There is no conflict of interest between the authors.

Informed Consent: Consent was obtained from the patient.

Çıkar Çatışması: Yazarlar arasında çıkar çatışması yoktur.

Hasta Onamı: Hastadan onam alınmıştır.

\section{REFERENCES}

1. Al-Daraji WI, Makhlouf HR, Miettinen M, Montgomery EA, Goodman ZD, Marwaha JS, et al. Fanburg-smith, primary gallbladder sarcoma a clinicopathologic study of 15 cases, heterogeneous sarcomas with poor outcome, except pediatric botryoid rhabdomyosarcoma. Am J Surg Pathol. 2009;33:6.

\section{[CrossRef]}

2. Husain EA, Prescott RJ, Haider SA, Al-Mahmoud RW, Zelger BG, Zelger B, et al. Gallbladder sarcoma: a clinicopathological study of seven cases from the UK and Austria with emphasis on morphological subtypes. Dig Dis Sci. 2009;54(2):395400. [CrossRef]

3. Kanthan R, Senger JL, Ahmed S, Kanthan SC. Gallbladder cancer in the $21^{\text {st }}$ century. J Oncol. 2015;2015:967472. [CrossRef]

4. Albores-Saavedra J, Cruz-Ortiz H, Alcantara-Vazques A et al. Unusual types of gallbladder carcinoma. A report of 16 cases. Arch Pathol Lab Med. 1981;105:287-93.

5. Brunicardi FC, Schwartz's Principle of Surgery, Tenth Edition, 2016, p1334-6.

6. Miettinen M, Lasota J. Gastrointestinal stromal tumors: review on morphology, molecular pathology, prognosis, and differential diagnosis. Arch Pathol Lab Med. 2006;130:146678.

7. Lopes CV, Rigon P, Zettler CG, Hartmann AA, Differential diagnosis of mesenchymal neoplasms of the digestive tract by cell block and immunohistochemistry. Cytopathology. 2018;29(6):531-6. [CrossRef] 